\title{
Book Review on Wilsonian Armenia: Stories behind the Failed Project by Rouben Ambartzumian
}

\author{
Claude Mutafian ${ }^{1,2}$ \\ ${ }^{1}$ Paris 13 University, Villetaneuse, France \\ ${ }^{2}$ Armenian Academy, Yerevan, Armenia \\ Email: claude.mutafian@wanadoo.fr
}

How to cite this paper: Mutafian, C. (2017) Book Review on Wilsonian Armenia: Stories behind the Failed Project by Rouben Ambartzumian. Open Journal of Social Sciences, 5, 157-161.

https://doi.org/10.4236/jss.2017.52015

Received: January 22, 2017

Accepted: February 17, 2017

Published: February 20, 2017

Copyright $\odot 2017$ by author and Scientific Research Publishing Inc. This work is licensed under the Creative Commons Attribution International License (CC BY 4.0).

http://creativecommons.org/licenses/by/4.0/

\begin{abstract}
The present book deals with a topic which has often been mentioned by various specialists of the Armenian question, but, as far as I know, never been studied per se. Rouben Ambartzumian [below quoted as RA] has decided to dig the question in order to understand and explain why the pro-Armenian projects of US president Woodrow Wilson turned to a total failure. Himself a brilliant world-famous mathematician, RA explores the field scientifically, as thoroughly as possible, in order to find, or eventually to guess, the reasons of the behaviour of the different actors of this tragedy.
\end{abstract}

\section{Keywords}

Sykes-Picot Agreement, Russian Occupation of Western Armenia, Armenian Red Army, London Conference, Lausanne Conference

\section{Ambassador Morgenthau Case}

The genocide of the Armenians in the Ottoman Empire began in 1915, and for several decades, until recently, the historical proofs were essentially based on three books: while "The Treatment of Armenians in the Ottoman Empire, 1915-16" by Viscount James Bryce and Arnold Toynbee (1916) and "Deutschland und Armenien, 1914-1918" by Dr. Johannes Lepsius (1919) are collections of documents, Henry Morgenthau, US ambassador in Constantinople from December 1913 to January 1916, published in 1918 his memoirs under the title "Ambassador Morgenthau's Story" [below quoted as Story] ${ }^{1}$. These authors have

${ }^{1}$ Story-famous "Ambassador Morgenthau's Story", first serialized in American magazine The World's Work in 1918 and then repeatedly published as a book (first by Doubleday Publishers). 
always been considered as friends and benefactors of the Armenians, totally devoted to their cause (p. 16). While this is absolutely correct for the three first ones, the case of Morgenthau is much more complex, as RA makes it clear along the pages of his book. He recalls the dinner with Talaat and Rabbi Nahoum on April 24, 1915, the very day of the beginning of the Genocide: "We asked him [Talaat] about the Armenians and he admitted he arrested a great many of them", an affirmation which did not prevent Morgenthau to deliver a speech at Robert College the next day, "replacing an Armenian Minister" who had been arrested (pp. 20-21). There is no record of any "writings and speeches" by Morgenthau during the crucial 1915 year (p. 17), and while the German Ambassador "filed a protest against Armenian horrors" in August 1915, there has been no "protest of comparable level" on the US side (p. 93). Roughly speaking, Morgenthau is presented as a cynical politician, essentially favourable to the Ottoman Empire, supporter of its territorial integrity and opposed to an eventual US declaration of war against it (p. 8).

\section{President Wilson's Position}

On the contrary, the other main character of the book, President Wilson, is described as desperately fighting in front of the Congress in order to get its approval for a declaration of war. The US declared war against Germany in April 1917, but when in December Wilson tried to extend it to Germany's allies, Turkey, Bulgaria and Austro-Hungary, only the last point was approved (p. 71).

More generally, RA recalls that the US was never in war with the Turks during WWI (p. 137). Many other clarifications are to be found in his book. For instance, he insists that, if Wilson personally signed the Versailles Treaty of 1919, the US did not (p. 138), neither did they recognize the Sevres Treaty the following year (p. 142). As for the 1918 Armenian Republic, here called "Talaat-Trotsky Armenia", RA claims that, paradoxically, its "guarantee could be offered only by the Turkish army" (pp. 127-128) and it "received no recognition from the WWI victors" (p. 137). The author insists also on the similarity between "the South-Western boundary" of the 1916 Sykes-Picot agreement and the one of the 1920 Wilsonian Armenia (pp. 53-54).

\section{Conferences, from London to Lausanne}

Particularly interesting is the way RA concludes his study. At the London Conference, held in early 1921, after the Sovietization of the Republic of Armenia and the abandon of the Sevres Treaty "with Wilson out of office", a "National Home" was, according to the author, proposed in the territories of Kars and Ardahan as an alternative to the late "Wilsonian Armenia", but this last hope disappeared in 1922with the deal made at the Lausanne Conference between Lord Curzon and Kemalist Turkey: the former "totally abandoned the idea of Armenian national home" in return for "the oil-rich Mosul province to British mandate" (pp. 145-150). 


\section{Rebuses of Musa Dagh}

In some cases, RA questions the common versions of such or such event by simply raising questions of good sense. This is the case in the chapter "The Rebuses of Musa Dagh" (pp. 74-87), where RA deals with the story popularized by Franz Werfel's “The Forty Days of Musa Dagh": 5.000 Armenians had taken refuge on the Musa Dagh in September 1915 and, after repelling constant Turkish attacks during 40 days, they waved a white flag towards some French warships who finally rescued them. RA insists that it is hard to imagine how French ships could approach an enemy coastline and collect thousands of refugees. He proposes a new version, based on a letter of the US Consul in Aleppo telling that, having been informed of the situation of the Armenians on the Musa Dagh, he brought "the matter to the attention of French fleet" and secured "permission from the Turkish authorities" for the rescue operation. RA concludes that, not being in a state of war with the Turks, Morgenthau was able to make a deal with them, arranging a peaceful salvation in order to avoid an eventual Entente landing. This interpretation makes sense, and RA points out the interesting fact that, in Story, Morgenthau is silent about this episode. The question of an eventual landing is more generally discussed: why did the Entente never consider landing in the so-called "soft abdomen" of Turkey, i.e. the Asiatic coast, mainly Cilicia or Syria (p. 50, 101), in spite of the calls of some Armenian organizations ready to send volunteers? Britain "declined to take up most of these Armenian proposals", which, as RA claims, was "in complete accord with Britain's pledge not to attack Turkey's soft abdomen, in fulfilment of probable Morgenthau's guarantees given to Turkey" (p. 81). Here, the explanation falls a little bit short.

\section{5. "Diary"2 against "Story"}

One of the main arguments of RA against Morgenthau is the comparison between his Story and his Diary published much later, in 2004. Particularly interesting is the way he recalls his farewell visit to Talaat, in January 1916, just after having been dismissed (pp. 23-24). In Story he insists on having questioned the Vizir about the fate of the Armenians, but the Diary is silent about that. The same divergence can be noted about his farewell audience with the Sultan (pp. 61-62). Even more, while the first part of Story does "not mention the Armenian issue", the second half "contains severe allegations against Turkey" and about the Armenian massacres. RA is probably right when he concludes that the text of Story has been rewritten by the State Department at a time when "Wilson was in need for a solid piece of anti-Turkish propaganda" (pp. 22-25). In other words, some parts of Story are not from Morgenthau's pen, they were used as a tool for Wilson's goal: a US declaration "of war on Turkey".

\section{Motivations}

There is sometimes in the book an excess of Manicheism. For example, present-

${ }^{2}$ Diaries_ "United States Diplomacy on the Bosphorus, the Diaries of Ambassador Morgenthau, 1913-1916”, published in 2004 by “Gomidas Institute”, Princeton and London. 
ing the mean Morgenthau as totally indifferent to the Armenian question, essentially preoccupied by his friendship with the Turks and the attempts to transfer East European Jews to Ottoman areas (p. 29, 38, 45), is as schematic as showing the nice Wilson obsessed by the fate of Western Armenia (p. 63, 124, 139); maybe Wilson needed Armenians and Western Armenia in order to justify the entrance in WWI. Both men were politicians, and for them the Armenian question was just a part of a much larger game: neither is totally black or white. Anyway, RA's approach deserves a further analysis.

About Franz Werfel's book, which is nothing more than a novel, RA insists that it propagated a distorted vision of the Musa Dagh episode, apparently well accepted in Nazi Germany. According to him, it "was coherent to some directions in Nazi propaganda" and directed against British rule in Palestine. $\mathrm{He}$ claims that the way Werfel got a US visa in 1940 German-occupied France supports his conjecture, and that "professional propagandist Werfel came to America in order to work for Hitler propaganda". These ideas are new but need a much more thorough study before being accepted. In the same way, Werfel's eventual denunciation, before his death, of his proper work "as too anti-Turkish" is only based on "rumours", as RA himself says (pp. 84-87): this does not constitute any concrete proof.

\section{Did Morgenthau Meet Trotsky?}

Although his argument is not quite convincing, RA suggests that Morgenthau might have met Leon Trotsky (p. 45). According to him, the Russian revolutionary carried the responsibility of the return of Van to the Turks in 1917 (p. 57); the next year he "was the head of the Russian delegation to Brest-Litovsk negotiations", where he let Germany occupy some Eastern provinces of the former Russian Empire and he negotiated with Talaat "the end of Russian occupation of Western Armenia" (pp. 44-45). The "return of Western Armenia to Turkey" was also a result of the failure of Wilson's June 1917 plan "about sending a Peace mission to Turkey to try to draw Ottomans out of the war", a failure due to Morgenthau, to Chaim Weizmann, representing "Zionist plans for British Palestine", and to Trotsky who, according to RA, was willing to turn "Russia into a country of anarchy, dissolution and ruin" that would surrender Western Armenia to Turkey (pp. 69-70). The author recalls that, after his disgrace, Trotsky "moved to Kemalist Turkey in 1929" (p. 45), where he spent a few years in the Bosphore islands. According to RA there were two duets, Wilson-Lenin "defying the Trotsky-Talaat agreement on Caucasus signed at Brest-Litovsk", while Trotsky's "aim was to dismantle the Russian Empire" (pp. 125-127). One may propose a different analysis, considering that, for Trotsky, Armenia was nothing but a marginal subject: while there is no doubt that his policy was disastrous for $\mathrm{Ar}$ menia, it was certainly not his main goal, but rather a consequence of a broader frame. On the other hand, blaming Trotsky so heavily leads more or less directly to praise Lenin and Stalin (p. 59), which puts one badly at ease, taking in account the latter's well-known armenophobia. It is true that in some cases Lenin and 
Stalin took certain pro-Armenian decisions, like the creation, in January 1918, of the so-called "Armenian Red Army" (p. 131), but it was only because these measures fitted their plans to give Soviet Russia the total territory of the lost Russian Empire: they do not result from any armenophile feeling.

\section{Models}

Some of the assertions in the book are lacking what could be called a complete proof; in these cases RA conveniently resumes them as "models" having a high probability. Yet the amount of evidence is mostly enough to keep the "model" in the mind of the reader as conclusive affirmations. Obviously RA likes to decode some names, but his proposals are not always convincing (pp. 28-29, 108, 120). I consider also that the responsibility of Britain's and France's dirty diplomacy is not enough emphasized.

\section{Attention to Zionism}

The main negative non-Turkish characters in RA's book are Morgenthau, Trotsky, Werfel, Weizmann, Rabbi Nahoum: all happen to be Jews. Although RA does not mention explicitly this coincidence, he gives considerable attention to Zionism, Jewish colonization of Palestine, Russian Jews, transfer of Jews to Egypt, and so on (p. 38, 41, 45, 98). Here one can feel an influence of the well known book by Yair Auron "Zionism and the Armenian Genocide, The Banality of Indifference". For that book Yair Auron was decorated by the Order of Mesrob Mashtotz, the highest reward of independent Armenia.

\section{Conclusion}

In conclusion, in spite of these reserves, this book is very important. It gives answers to many complex problems and shows brilliantly why "Wilson's Armenia" ended as a failure. Even more, it sets the pendulums right and offers a new explanation of some aspects of history hitherto overlooked or distorted by routine versions.

\section{Scientific Research Publishing}

Submit or recommend next manuscript to SCIRP and we will provide best service for you:

Accepting pre-submission inquiries through Email, Facebook, LinkedIn, Twitter, etc. A wide selection of journals (inclusive of 9 subjects, more than 200 journals)

Providing 24-hour high-quality service

User-friendly online submission system

Fair and swift peer-review system

Efficient typesetting and proofreading procedure

Display of the result of downloads and visits, as well as the number of cited articles

Maximum dissemination of your research work

Submit your manuscript at: http://papersubmission.scirp.org/

Or contact jss@scirp.org 